\title{
COMPARATIVE ANALYSIS OF THE DYNAMICS OF HEALTHCARE EXPENDITURES FROM COUNTRY GDP AND CASH PAYMENTS OF FAMILIES TO MEDICAL AND PHARMACEUTICAL SUPPORT IN UKRAINE, CIS COUNTRIES AND EU
}

\author{
O. Samborskyi, M. Slobodyanyuk, H. Panfilova
}

\begin{abstract}
Мета: проведення порівняльного аналізу динаміки змін витрат (\%) на охорону здоров'я від ВВП країн та готівкових виплат родин на медичне й фармачевтичне забезпечення від загальних витрат на охорону здоров'я в Украӥні, краӥнах СНД та ЄС (членів з 2004 р.).

Матеріали і методи. Використовувалися дані Свропейського регіонального бюро ВООЗ та такі методи аналізу, як історичний, аналітико-порівняльний, системний, логічний, графічний, математикостатистичний та ін..

Результати дослідження. За результатами проведеного аналізу встановлено, щуо витрати (\%) на охорону здоров'я від ВВП країн та готівкові виплати (\%), щзо здійснюються родинами на медичне та фармацевтичне забезпечення від загальних витрат на охорону здоров'я протягом 1990-2014 років планомірно збільшувалися. При иььому доведено, щчо темпи (\%) зростання зазначених показників в Україні, країнах СНД та ЕС відрізнялись як за циифровими значеннями, так й по роках дослідження. Найбільші та найменші значення приросту зазначених показників були характерні для Украйни. Крім цього, саме вітчизняні показники мали зигзагоподібний характер їх змін, наприклад, витрати (\%) на охорону здоров'я від ВВП країни в у 1995 рочі зросли до 7,0 \% з 3,3 \% (1994 р.). Доведено, щзо в Україні протягом 1990-2014 р. на фоні збільшення витрат (\%) на охорону здоров'я від ВВП країни у 2,14 разів готівкові (\%) виплати населення від загальних витрат на охорону здоров'я зросли у 1,9 разів. В країнах СНД за аналогічний період вищевказаний показник витрат зріс в 1,7 разів, а готівкові виплати родин 1,8 разів, а у краӥнах EC - у 1,4 рази та 1,04 рази відповідно. Таким чином можна стверджувати, що населення європейських країн, на фоні планомірного зростання витрат (\%) на охорону здоров'я від ВВП краӥни стабільно витрачає у вигляді готівкових виплат на медччне та фармацевтичне забезпечення не більше 25,0\% від загальних витрат в національних системах охорони здоров'я.
\end{abstract}

Висновки. Наявність нестабільної динаміки змін зазначених макроекономічних показників в Украӥні та краӥнах СНД, порівняно з аналогічними даними, які представлені по країнах ЄС є наслідком відсутності системного бачення прочесів реформування начіональних систем охорони здоров'я, а також послідовної політики держави у напрямку ефективного фінансового забезпечення прочесу надання населенню медичної та фармачевтичної допомоги

Ключові слова: медччна допомога, витрати на охорону здоров'я; готівкові виплати родин на медичне та фармацевтичне забезпечення, охорона здоров'я, фармачевтична допомога

Copyright (C) 2020, O. Samborskyi, M. Slobodyanyuk, H. Panfilova. This is an open access article under the CC BY license (http://creativecommons.org/licenses/by/4.0).

\section{Introduction}

The implementation of various government programs aimed at increasing the level of accessibility of medical and pharmaceutical care to the population is impossible without analyzing the dynamics of changes in macroeconomic indicators of health care development [1, 2]. In recent years, more and more attention is paid to the analysis of the possibilities of certain health care systems to ensure a decent, socially determined level of accessibility of services provided to the population in the public health sector [3, 4]. Given the permanent deficit of the state budget and public funds, the issue of transferring the share of health care expenditures to private entities remains acute [5], first of all insurance companies for the organization of medical services, etc. $[6,7]$. At the same time, it is unquestionable that the expenditures of the state budget and public funds aimed at health care will gradually decrease even in countries with socially oriented vectors of development $[8,9]$. This is an objective process, which is associated with a number of factors [10, 11], among which the constant desire of people to receive quality and timely medical and pharmaceutical care is a priority $[12,13]$. Scientists note that global health care expenditures are increasing at a much faster rate $(\%)$ than the growth of key macroeconomic indicators in most countries $[14,15]$. At the same time, the issue of financial support from the state and public institutions of the level of guaranteeing the physical and socio-economic accessibility of medical and pharmaceutical services to the lowincome population remains open $[16,17]$. 
In order to maintain social stability in society in many countries around the world were developed and successfully implemented numerous programs to support low-income citizens to preserve their health through public or state funds $[2,17]$, such as the Ukrainian program "Available medicine". In order to develop effective directions for the implementation of these measures, the results of the analysis of the main macroeconomic indicators that affect the level of physical and socioeconomic accessibility of services provided in the health care system are used $[18,19]$. These indicators, presented on the official website of the World Health Organization (WHO) include the cost $(\%)$ of health care from gross domestic product (GDP) and cash costs (\%) of families for medical and pharmaceutical care from the general health care costs $[20,21]$. Given the fact that in recent years Ukraine has declared at the state level intentions for the European integration vector of development in a range of social activities, the issues of comparative analysis of key macroeconomic indicators affecting the availability of medical and pharmaceutical care are relevant and practical $[22,23]$.

The aim of the study was to conduct a comparative analysis of the dynamics of macroeconomic indicators of health care expenditures (\%) of GDP and cash payments $(\%)$ of families for medical and pharmaceutical services in total health care expenditures in Ukraine, CIS and EU countries.

\section{Research planning (methodology)}

In order to effectively fulfil the main purpose of research, we have outlined the following stages of applied research:

- previous: determining the socio-economic relevance of research in this area, taking into account the requirements of today, primarily in the direction of implementing socially oriented government programs and projects aimed at increasing the availability of medical and pharmaceutical care and the formation of socially oriented assortment policy in the domestic pharmaceutical market under the conditions of the existing resource provision of the health care system; analysis of existing publications in this direction; outlining previously unresolved issues on this issue;

- structurally complex: identification of objects and research methods; selection of software products for statistical processing of statistical data; formation of a reference group of countries; outlining the objective limitations of the research itself and the use of their results in practice at various levels of the organization of medical and pharmaceutical services to the population;

- effectiveness and calculation: conducting a comparative analysis of relevant macroeconomic indicators in the dynamics of years in Ukraine and in the group of reference countries; mathematical processing of relevant data and determining the level of their reliability using standardized packages of statistical analysis; identification of the main trends in changes in these indicators;

- final: systematization and generalization of the obtained results; determination of perspective directions of carrying out researches in the specified direction.
The design of the research was built in such a way that all stages of its implementation are interconnected, and their implementation allows, in our opinion, to fully resolve the purpose of the work.

\section{Materials and methods}

The object of the study was selected data presented on the official website of the WHO, the European Regional Office, namely the European Health Information Portal [20]. We used macroeconomic data presented for 19902014 , namely health care expenditures $(\%)$ of the country's GDP and families 'cash payments (\%) for medical and pharmaceutical provision in total health care expenditures. Characteristics of these indicators in accordance with the wording of the WHO are presented in Tab. 1. For the convenience of analysis, expenditures $(\%)$ on health care from the GDP of the countries received the symbol "A", and cash payments (\%) of families for medical and pharmaceutical support in the total expenditure on health care - "B". Given the fact that we analyzed the data in a significant time interval (indicator "A" from 1990 to 2014; indicator "B" from 1995 to 2014), the analysis of the dynamics of changes in indicators was carried out on indicative points, which were determined at equal intervals. Thus, the analysis of changes in indicator " $\mathrm{A}$ " was carried out for 1990, 1994, 1999, 2004, 2009 and 2014, respectively, and the data on indicator " $\mathrm{B}$ " were analyzed for 1995, 1999, 2004, 2009 and 2014.

One of the key points in the construction of the research design was the definition of a group of reference countries for Ukraine. To do this, we used two approaches at the same time, namely guided by the historically formed features of the functioning of the health care system of Ukraine for a long time, and on the other - took into account the European integration intentions for further development of the country. Historically, the domestic health care system and the pharmaceutical supply system have long functioned on the basis of budget financing with elements of market relations, which developed mostly spontaneously under relatively weak and ineffective government mechanisms to regulate the availability of medical and pharmaceutical care. Such a paradoxical symbiosis in health care has led to the formation of a complex of contradictions between the resource potential of the industry and the needs of the population in the increased level of provision of relevant services. It should be noted that in similar conditions functioned most of the countries that were part of the former Soviet Union. Therefore, the first group of reference countries were the member states of the Union of Independent States (CIS), of which Ukraine was a member until May 22, 2018. Given Ukraine's European integration intentions for its gradual reintegration into the political, economic and social structures of the EU, the second group of reference countries countries were elected, the so-called "new members of the EU", which joined the association in May 2004. The accession of 8 countries (Czech Republic, Estonia, Hungary, Lithuania, Latvia, Poland, Slovakia and Slovenia) to the EU became one of the largest in terms of implementation by the association of countries, both in human and territorial terms. At the same time, the EU includes countries with relatively low levels of economic development and all state infra- 
structure compared to other European countries. Given the above, we believe that the comparison of Ukrainian macroeconomic indicators that affect the level of availability of medical and pharmaceutical services with the relevant data in the CIS and EU countries that joined the association since 2004 is correct.

Characteristics of the main macroeconomic indicators of the analysis (WHO edition) [20]

\begin{tabular}{|l|l|}
\hline \multicolumn{1}{|c|}{$\begin{array}{c}\text { Symbol of the indicator in the } \\
\text { analysis }\end{array}$} & \multicolumn{1}{c|}{ Characteristics of the indicator } \\
\hline $\begin{array}{l}\text { Indicator "A" Health care expend- } \\
\text { itures (\%) of the country's GDP }\end{array}$ & $\begin{array}{l}\text { This indicator is calculated by the WHO in accordance with the classification of } \\
\text { national health accounts (World Health Report 2006, www.who.int). The sources } \\
\text { are data provided by countries, as well as the results of the assessment of interna- } \\
\text { tional organizations, such as the International Monetary Fund, the World Bank, } \\
\text { the United Nations, the Organization of Economic cooperation and development, } \\
\text { etc. As a result, the presented indicators may differ from those presented by coun- } \\
\text { tries. }\end{array}$ \\
\hline $\begin{array}{l}\text { Indicator "B" Cash payments (\%) } \\
\text { of families for medical and phar- } \\
\text { maceutical support from the total } \\
\text { cost of health care }\end{array}$ & $\begin{array}{l}\text { Cash payments of families, including various forms of payment to health care } \\
\text { orkers and suppliers of medicines or other goods and services, the main purpose } \\
\text { of which is to help restore or strengthen the health of individuals or groups of the } \\
\text { population. These include family payments to government services, non-profit } \\
\text { institutions and non-governmental organizations, as well as those payments that } \\
\text { are not reimbursed from any funds, deductibles, joint payments for the provision } \\
\text { of services. The calculations do not take into account the health care payments } \\
\text { made by companies that provide medical and paramedical services, whether per- } \\
\text { mitted by law or not, to their employees. Expenses related to treatment abroad are } \\
\text { also excluded. }\end{array}$ \\
\hline
\end{tabular}

In our research we used both general theoretical (historical, systemic, logical, analytical-comparative, hypothetical-deductive, etc.) and applied methods used in organizational and economic research in pharmacy and health care. The analysis of the dynamics of changes in quantitative indicators was carried out by calculating the rates of growth $(\mathrm{Rg}$., \%) and rates of increase (Ricr., \%) of the relevant data. Both chain and basic indicators of rates of growth and increase of indicators "A" and "B" were calculated. According to the presented data on the official website of the WHO for indicator "A" the base year in the analysis was 1990, and for indicator "B" - 1995. The interval of fluctuations of the analysis was analyzed using calculations of variation scale ( $\mathrm{R}=\mathrm{x} \max -\mathrm{x} \min )$. The required data processing was performed using standard statistical analysis packages Statistica (version 12.0, StatSoft, Tulsa, USA) and Excel spreadsheet. A value of $\mathrm{p}<0.05$ was considered statistically significant.

\section{Results}

Data from statistical processing of macroeconomic indicators "A" and "B" are presented in Table 2.

As we can see, the indicator "A" during 19902014 in Ukraine and by the group of reference countries tended to increase. For example, in Ukraine it has more than doubled (from $3.5 \%$ to $7.1 \%$ ), in the CIS countries 1.7 times (from $3.9 \%$ to $6.6 \%$ ), and in countries EU 1.4 times (from $4.9 \%$ to $6.77 \%$ ). At the same time, the highest average value of this indicator was typical for the EU countries $(6.08 \%)$ ). It should be noted that the highest value of the average rate of indicators increase (Ricr.av. $=5.0 \%$ ) was typical for Ukraine, and the lowest (Ricr.av. $=1.0 \%$ ) for the EU countries. The value of the variation scale of indicator " $\mathrm{A}$ " in Ukraine was $4.5 \%$, in the CIS countries - $2.84 \%$, and in the EU countries $-2.2 \%$. That is, it can be argued that it is in the Ukrainian realities that such an important macroeconomic indicator, which is the cost $(\%)$ of health care from the country's GDP had the largest scope of fluctuations. In the EU countries, the opposite trend was observed, i.e. fluctuations in this indicator were observed in a relatively small range of values. The highest values of " $A$ " were typical for Ukraine in $2009-7.8 \%$, and the lowest $3.3 \%$ again for Ukraine in 1991, 1993 and 1994. In turn, the highest values of $\mathrm{Rg}$. (\%) was typical for domestic indicators "A". Thus, in 1995 the indicator " $\mathrm{A}$ " was equal to the value of $7.0 \%$, which is 2 times higher than the value $(3.3 \%)$ of the previous year (Rg.chain= $=212.0 \%$ ). The lowest value of Rg.chain. observed simultaneously in Ukraine and the CIS countries in 1999. Thus, in Ukraine in 1999 this figure decreased from 6.60 $\%$ to $5.89 \%$, and in the CIS countries from $6.33 \%$ to $5.63 \%$. Thus, Rg.lants. in both cases the value was $89.0 \%$. In Fig. 1. the results of the analysis of dynamics of changes of an indicator " $A$ " on indicative points are presented. As we can see, Ukraine and the CIS countries are characterized by a zigzag characteristic of the change in " $A$ " in the dynamics of the years against the gradual growth of similar data for the group of EU countries. Thus, in Ukraine there was a decrease in data from $3.5 \%$ in 1990 to $3.3 \%$ in 1994, with already in 1999 there was a significant increase in this indicator by 1.8 times. 
Table 2

Analysis of macroeconomic indicators affecting the availability of medical and pharmaceutical care (WHO data)

\begin{tabular}{|c|c|c|c|c|c|c|c|c|c|c|c|c|}
\hline \multirow[b]{3}{*}{ Years } & \multicolumn{6}{|c|}{ Indicator «A» } & \multicolumn{6}{|c|}{ Indicator $« B »$} \\
\hline & \multicolumn{2}{|c|}{ Ukraine } & \multicolumn{2}{|c|}{ CIS countries } & \multicolumn{2}{|c|}{ EU countries } & \multicolumn{2}{|c|}{ Ukraine } & \multicolumn{2}{|c|}{ CIS countries } & \multicolumn{2}{|c|}{ EU countries } \\
\hline & $\%$ & $\begin{array}{c}\text { Rate of } \\
\text { increase, } \\
\%\end{array}$ & $\%$ & $\begin{array}{c}\text { Rate of } \\
\text { increase, } \\
\%\end{array}$ & $\%$ & $\begin{array}{c}\text { Rate of } \\
\text { increase, } \\
\%\end{array}$ & $\%$ & $\begin{array}{c}\text { Rate of } \\
\text { increase, } \\
\%\end{array}$ & $\%$ & $\begin{array}{c}\text { Rate of } \\
\text { increase, } \\
\%\end{array}$ & $\%$ & $\begin{array}{c}\text { Rate of } \\
\text { increase, } \\
\%\end{array}$ \\
\hline 1990* & 3.5 & - & 3.9 & - & 4.9 & - & $-* *$ & -** & $-* *$ & $-* *$ & $-* *$ & -** \\
\hline 1991 & 3.3 & -6.0 & 3.8 & -3.0 & 5.4 & 10.0 & $-* *$ & -*** & $-* *$ & $-* *$ & -*** & -*** \\
\hline 1992 & 3.4 & 3.0 & 3.8 & 0.0 & 5.4 & 0.00 & $-* *$ & - $* *$ & -** & $-* *$ & -*** & - *** \\
\hline 1993 & 3.3 & -3.0 & 4.0 & 5.0 & 5.3 & -2.0 & - $* * *$ & - $* * *$ & - $* *$ & - $* *$ & - $* *$ & - $* * *$ \\
\hline 1994* & 3.3 & 0.0 & 5.0 & 25.0 & 5.5 & 4.0 & $-* *$ & - $* *$ & $-* *$ & - $* *$ & $-* *$ & - $* * *$ \\
\hline 1995 & 7.0 & 112.0 & 5.79 & 16.0 & 5.32 & -3.0 & 24.5 & $-*$ & 25.6 & $-^{*}$ & 22.4 & -* $^{*}$ \\
\hline 1996 & 6.85 & -2.0 & 5.88 & 2.0 & 5.45 & 2.0 & 26.8 & 9.0 & 26.6 & 4.0 & 23.3 & 4.0 \\
\hline 1997 & 6.85 & 0.0 & 6.7 & 14.0 & 5.48 & 1.0 & 35.5 & 33.0 & 28.2 & 6.0 & 22.4 & -4.0 \\
\hline 1998 & 6.60 & -4.0 & 6.33 & -5.0 & 5.57 & 2.0 & 43.0 & 21.0 & 33.2 & 18.0 & 25.7 & 15.0 \\
\hline 1999* & 5.89 & -11.0 & 5.63 & -11.0 & 5.73 & 3.0 & 46.2 & 7.0 & 36.7 & 11.0 & 23.5 & -9.0 \\
\hline 1 & 2 & 3 & 4 & 5 & 6 & 7 & 8 & 9 & 10 & 11 & 12 & 13 \\
\hline 2000 & 5.58 & -5.0 & 5.35 & -5.0 & 5.71 & -1.0 & 44.1 & -4.0 & 37.9 & 3.0 & 24.4 & 4.0 \\
\hline 2001 & 5.66 & 1.0 & 5.46 & 2.0 & 5.91 & 4.0 & 41.8 & -5.0 & 37.8 & -1.0 & 24.1 & -1.0 \\
\hline 2002 & 6.25 & 10.0 & 5.76 & 6.0 & 6.19 & 5.0 & 40.4 & -7.0 & 38.4 & 2.0 & 22.7 & -6.0 \\
\hline 2003 & 6.93 & 11.0 & 5.73 & -1.0 & 6.45 & 4.0 & 38.7 & -4.0 & 39.3 & 2.0 & 22.2 & -2.0 \\
\hline 2004* & 6.61 & -5.0 & 5.52 & -4.0 & 6.44 & -1.0 & 38.6 & $\begin{array}{l}-1.0 \\
\end{array}$ & 39.5 & 1.0 & 25.3 & 14.0 \\
\hline 2005 & 6.41 & -3.0 & 5.54 & 1.0 & 6.48 & 1.0 & 37.5 & -3.0 & 38.3 & -3.0 & 23.5 & -7.0 \\
\hline 2006 & 6.39 & -1.0 & 5.54 & 0.0 & 6.36 & -2.0 & 36.3 & -3.0 & 37.2 & -3.0 & 23.8 & 1.0 \\
\hline 2007 & 6.36 & -1.0 & 5.52 & -1.0 & 6.37 & 1.0 & 34.7 & -5.0 & 37.1 & -1.0 & 23.1 & -3.0 \\
\hline 2008 & 6.63 & 4.0 & 5.99 & 9.0 & 6.69 & 5.0 & 39.4 & 14.0 & 42.8 & 15.0 & 22.8 & -1.0 \\
\hline 2009* & 7.80 & 18.0 & 6.97 & 16.0 & 7.1 & 6.0 & 42.0 & 7.0 & 43.7 & 2.0 & 23.3 & 2.0 \\
\hline 2010 & 7.81 & 1.0 & 6.53 & -6.0 & 7.02 & -1.0 & 40.5 & -4.0 & 43.7 & 0.0 & 22.1 & -5.0 \\
\hline 2011 & 6.98 & -11.0 & 6.21 & -5.0 & 6.82 & -3.0 & 43.6 & 8.0 & 44.2 & 1.0 & 23.0 & 4.0 \\
\hline 2012 & 7.47 & 7.0 & 6.6 & 6.0 & 6.80 & -1.0 & 42.0 & -4.0 & 43.6 & -1.0 & 23.1 & 1.0 \\
\hline 2013 & 6.67 & -11.0 & 6.74 & 2.0 & 6.76 & -1.0 & 43.1 & 2.0 & 45.9 & 5.0 & 23.4 & 1.0 \\
\hline 2014* & 7.10 & 6.0 & 6.6 & -2.0 & 6.77 & 1.0 & 46.2 & 7.0 & 46.2 & 1.0 & 23.3 & -1.0 \\
\hline $\begin{array}{c}\text { Average } \\
\text { value }\end{array}$ & 6.03 & 5.0 & 5.64 & 3.0 & 6.08 & 1.0 & 39.25 & 4.0 & 38.30 & 3.0 & 23.37 & 1.0 \\
\hline
\end{tabular}

Note: *-indicative points of comparative analysis of the dynamics of changes in indicators

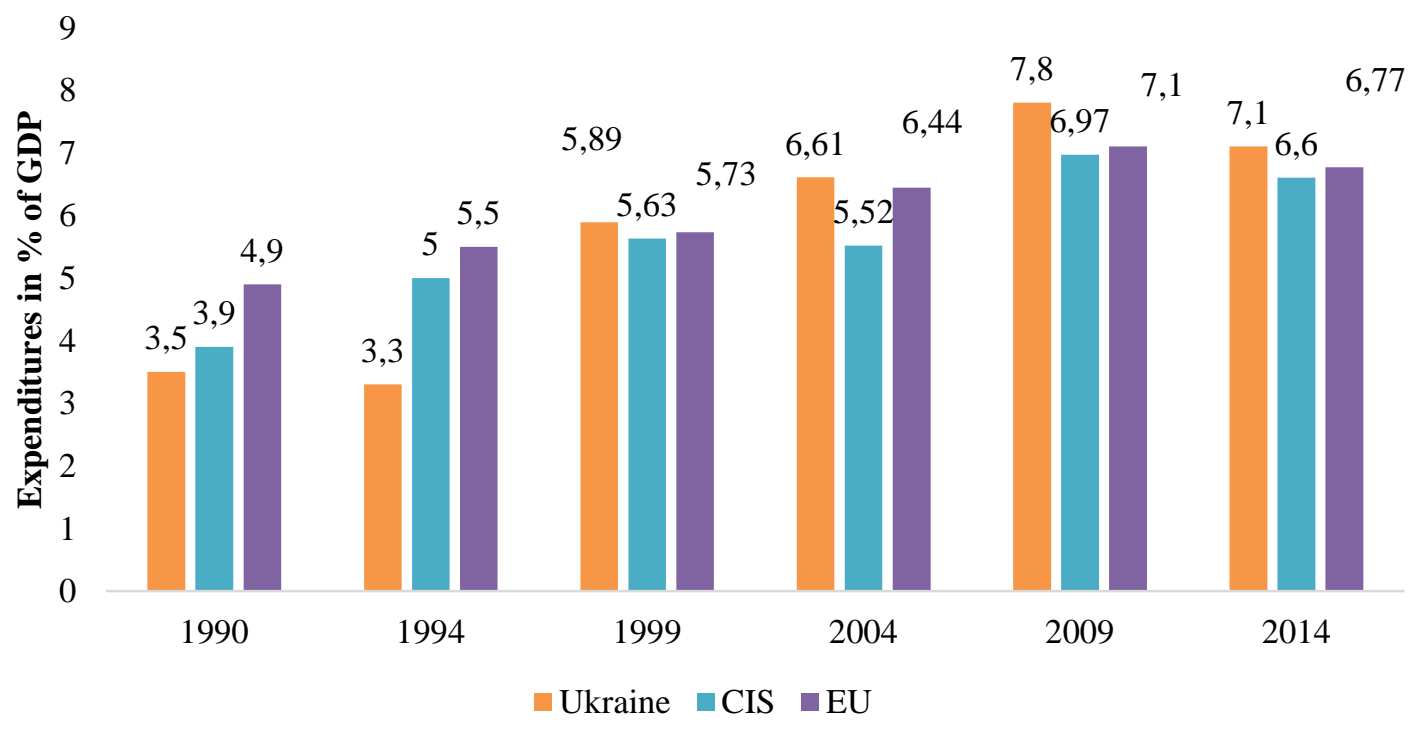

Fig. 1. Study of the dynamics of expenditures (\%) on health care from the country's GDP by indicative analysis points (WHO data)

The planned growth of the indicator " $A$ " was observed until 2009, and in 2014 there was again a decrease in data to $7.1 \%$ (Rg. 2014/2009=91.0\%). For the CIS countries, the data decline was characterized by a lower rate (\%) compared to Ukraine. Thus, in 2004 the indicator "A" decreased to $5.52 \%$, i.e. only by $2.0 \%$ 
(Rg. 2004/1999=98.0 \%). The next decrease in data was observed in 2014 to $6.6 \%$ (Rg.2014 / 2009=95.0 \%). In the EU countries during 1990-2005 there was a tendency to a gradual increase in indicators "A", and from 2011 to 2014 on the contrary - a slight decrease from $6.82 \%$ to $6.77 \%$. This trend is a logical reflection of the implementation of policies of most countries, aimed at curbing government and public spending on health care, which is observed against the background of permanent growth in the need for quality medical and pharmaceutical services $[6,17]$. Common for Ukraine, the CIS countries and the EU is the presence of the lowest data of the indicator "A" in 1990. In the future, the data presented are of different nature, with different growth rates $(\%)$ both in digital value and by years of study.

The following indicator of the analysis reflects the level of cash expenditures (\%), which are related to the organization of medical and pharmaceutical services from the total health care costs in the country. The indicator "B" fluctuated in Ukraine in the range of values from $24.5 \%(1995)$ to $46.2 \%(1999,2014)$, in the CIS countries from $25.6 \%$ (1995) to $46.2 \%$ (2014), and in the EU from $22.1 \%$ (2010) to $25.3 \%$ (2007) (Table 2). From 1995 to 2014, this indicator in all countries was characterized by an increase, with different rates (\%) of growth. Thus, in Ukraine it increased by $88.6 \%$, in the CIS countries by $80.5 \%$, and in the EU countries only by $4.0 \%$. The highest values of the indicator "B" were observed in Ukraine $(2014,1999)$ and the CIS countries (2014), and the lowest according to 2010 data in the EU countries $(22.1 \%)$. In turn, the highest values of growth rates (\%) were typical for Ukraine according to 1997 $(35.5 \%$, Rg.chain $=133.0 \%)$, and the lowest - for EU countries in $2006(25.3 \%$, Rg.chain $=92.9 \%)$.
It is interesting to compare the dynamics of changes in these indicators with data on indicators "A". Thus, in Ukraine, against the background of an increase in expenditures $(\%)$ on health care from the country's GDP during 1990-2014 by 2.14 times, cash payments $(\%)$ of families for medical and pharmaceutical provision of the population increased 1.9 times, in the CIS countries the " $A$ " indicator increased 1.7 times, and cash payments of families 1.8 times, in the EU countries 1.4 times and only 1.04 times, respectively. That is, the population of European countries consistently spent in the form of cash payments for medical and pharmaceutical care no more than $25.0 \%$ of total expenditures in national health care systems. This is an impressive statistic, which shows a sharp decline in the level of participation of state institutions, which are declared in the legislative documents of Ukraine and the CIS countries in the financial support of medical and pharmaceutical care during 1995-2014.

The average value of " $\mathrm{B}$ " in Ukraine was $39.25 \%$ with the average value of $\mathrm{Rg}$.chain $=104.0 \%$, in the CIS countries $38.3 \%$ (Rg.chain $=103.0 \%$ ), and in the EU $23.37 \%$ (Rg.chain $=101.0 \%$ ). As we can see, Ukraine was characterized by the highest value of the growth rate of the studied indicator. That is, almost every third hryvnia spent in the health care system in Ukraine is associated with direct cash payments to families, in contrast to EU countries, where the average citizen consistently spends for a long time (1995-2014) for these measures only every fourth currency.

In Fig. 2 the results of the analysis of the dynamics of changes in the indicator " $\mathrm{B}$ " on the indicative points of the analysis are presented.

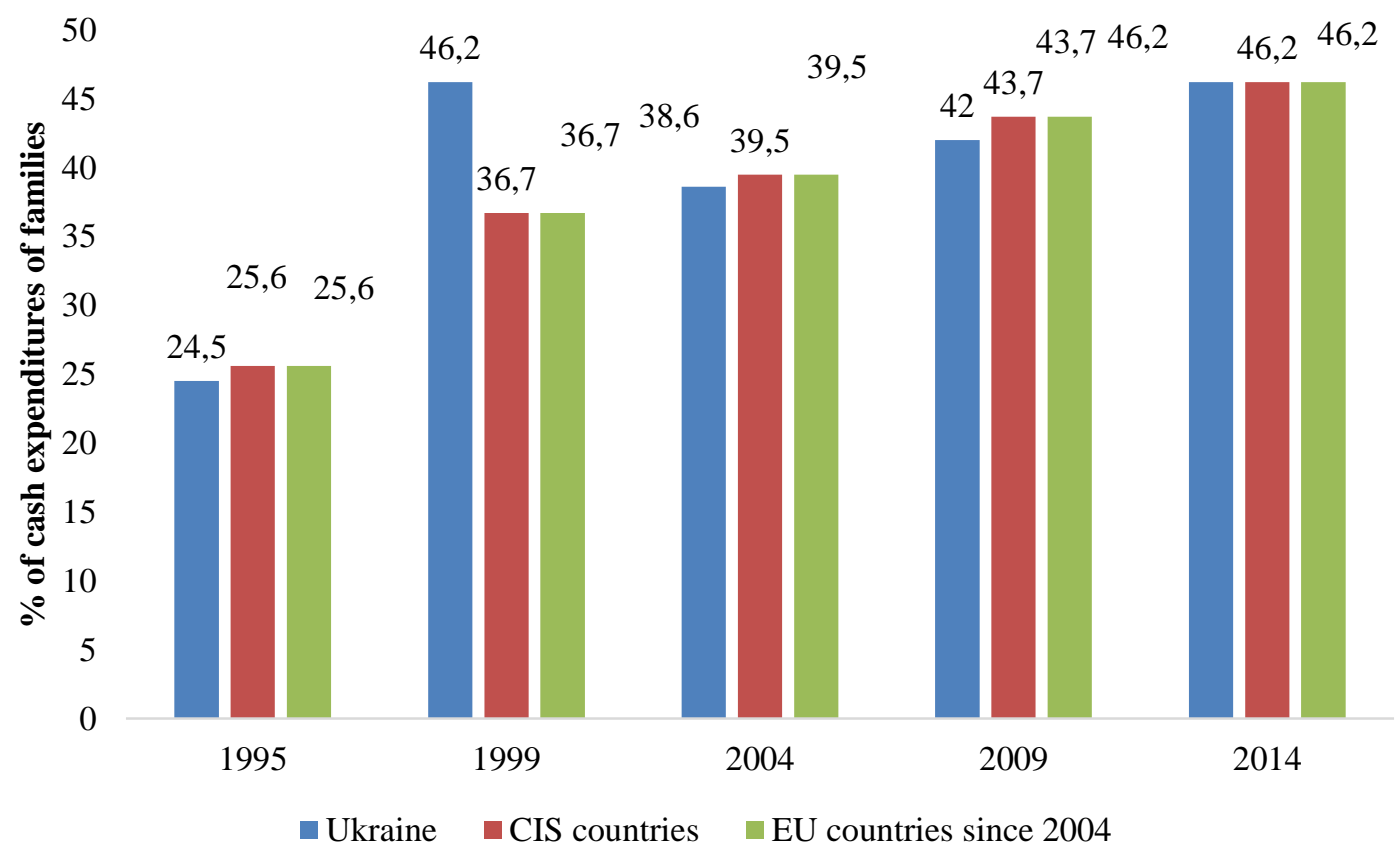

Fig. 2. Comparative analysis of the dynamics of families cash payments (\%)for medical and pharmaceutical support from the total cost of health care by indicative points (WHO data)

First of all, the significant growth of "B" in 1999 in Ukraine is noteworthy, compared to 1995. The pre- sented macroeconomic indicator has almost doubled, and in the CIS and EU countries it has increased by 1.4 times. 
That is, it can be argued that since 1999 in Ukraine began a process of gradual increase in the financial burden on citizens in the process of organizing the provision of medical and pharmaceutical services. Subsequently, this indicator in Ukraine has stabilized somewhat and according to 2004 it was $38.6 \%$, which is $16.45 \%$ lower than previous data for 1999. In general, it should be noted that the indicator " $\mathrm{B}$ ", as well as data indicators " $\mathrm{A}$ " during the time we studied, tended to increase in values with different rates of development of this process over time. This is a common characteristic of the dynamics of the indicators we considered.

\section{Discussion}

Systematizing the results of research, we can state the following. Expenditures (\%) on health care from the GDP of countries and cash payments (\%) made by families for medical and pharmaceutical support from the total expenditure on health care increased systematically during 1990-2014. It was proved that the growth rates (\%) of these indicators in Ukraine, CIS countries and the EU differed both in numerical values and by years of research. The largest and smallest values of growth of these indicators were, in most cases, typical for Ukraine. In addition, domestic indicators and data of the CIS countries had a zigzag nature of their changes, indicating the lack of a clear understanding of the state's reform of national health care, especially the introduction of effective mechanisms for its financing and rational use of limited resources. Undoubtedly, the growth rate of " $\mathrm{B}$ " in Ukraine and the CIS countries was much higher than similar data for the EU group. This is a characteristic feature that fundamentally distinguishes the essence of the development of the process we have considered. That is, in the EU countries, the increase in cash expenditures (\%) of families for medical and pharmaceutical services from the total health care expenditures is proportional to the increase in the data of indicator " $A$ ". For example, the average value for " $\mathrm{A}$ " and " $\mathrm{B}$ " is Rg.chain $=101.0 \%$. In Ukraine and the CIS countries, against the background of an increase in the " $\mathrm{A}$ " indicator, families' cash expenditures on medical and pharmaceutical provision of the population are also growing. This fact indirectly indicates the strengthening of tendencies to commercialization in the organization of medical and pharmaceutical services to citizens and the weakening of the role of state and public institutions in the financial provision of the population in the way of maintaining health. Against the background of the permanent growth of indicators " $\mathrm{A}$ " and "B", state and public institutions on the one hand must develop and implement rational mechanisms for monitoring the effective use of these funds. On the other hand, the experience of EU development suggests the need to implement reimbursement programs for the cost of consumption of medicines and medical services based on the real financial capabilities of the health care system and approved treatment protocols.

As a result of analysis of special literature, it can be argued that the analysis of key macroeconomic indicators that affect the level of availability of medical and pharmaceutical care to the population, the dynamics of the years is constantly given much attention, especially against the background of geopolitical processes occur- ring today $[1,5]$. It should be noted that these issues are considered by a wide range of professionals, from economists [6, 11], health insurers [5] to pharmacists [22, 23], health managers and representatives of basic science [7, 12]. This fact once again emphasizes the socio-economic significance of the results of the analysis of key macroeconomic indicators that should be used in the development of key strategies and areas for reforming domestic health care.

Study limitations. Objective limitations of research are related to the need to solve two sets of problems. First, according to comments on the official WHO website, the digital values of macroeconomic indicators may differ from those provided by national health systems. This is due to the peculiarities of the methods used for their calculation and approaches in the formation of the information base of sources of various international organizations (International Monetary Fund, The World Bank, United Nations, Organization for Economic Cooperation and Development, etc.). Therefore, the data presented on the official WHO website are more declarative and allow us to identify the main trends and problems of the process in retrospect over the years at the macroeconomic level of its consideration. In order to use them effectively in practice at the microeconomic level, it is necessary to make additional adjustments in accordance with the State Budget, national regulators of monetary and financial policy in the country, line ministries and other state institutions, in the competence of which the issues of resource provision of the process of providing medical and pharmaceutical care to the population are considered.

The second set of issues that need to be addressed concerns the factor analysis of the impact on the presented macroeconomic indicators in such areas as political, financial and economic, social and special (medical and pharmaceutical) risks. According to the National Strategy for Health Reform in Ukraine for 2015-2020, the country spends a significant part of GDP on health services, but the level of GDP per capita in Ukraine is lower than in most European countries. At the same time, many countries manage to achieve fairly good life expectancy and mortality rates with comparable health care costs [24]. That is, despite the significant increase in government spending (\%) of the country's GDP, the issue of increasing the relative accessibility of medical and pharmaceutical care to the population remains open and requires further research on a wide range.

Prospects for further research. Given the socioeconomic significance of the indicators we have analyzed over the years, one of the promising areas of our research will be an analysis of factors influencing the level of availability of medical and pharmaceutical care to the population of Ukraine. Particular attention will be paid to the impact of the political, socio-economic and financial crisis on the indicators of physical and socio-economic accessibility of medicines and medical devices in Ukraine.

\section{Conclusions}

The unstable nature of the dynamics of changes in these macroeconomic indicators in Ukraine and the 
CIS countries, compared to similar data presented in the EU is a consequence of the lack of a systematic vision of the processes of reforming national health systems and consistent state policy in direction of financial support of the process of providing medical and pharmaceutical care to the population. Most countries around the world are currently facing painful problems of health care shortages against the background of the ever-increasing needs of the population to provide quality and affordable medical and pharmaceutical care $[6,25]$. Such a severe challenge of today can only be considered constructively in terms of combining the efforts of all professionals working in the health care and pharmaceutical supply system. We believe that one of the effective ways to solve this problem is the development and implementation in the national pharmaceutical market of socially oriented product and product range, based on the principles of rational combination of resource capabilities of the state, business and public institutions with the needs of the population in the provision of medical and pharmaceutical services at the appropriate level.

\section{Conflict of interests}

The authors declare that they have no conflicts of interest.

\section{References}

1. Darvas Z., Moës, N., Myachenkova, Y., Pichler, D. (2018). The macroeconomic implications of healthcare. Policy Contribution, 11. Available at: https://www.bruegel.org/wp-content/uploads/2018/08/PC-11_2018_cover.pdf

2. Pakdaman, M., Geravandi, S., Askari, R., Askarishahi, M., Reza Afzali, H. (2019). The effect of macroeconomic indicators on health-care expenditure in Iran. Journal of Education and Health Promotion, 8 (1), 123.

3. Reeves, A., McKee, M., Basu, S., Stuckler, D. (2014). The political economy of austerity and healthcare: Cross-national analysis of expenditure changes in 27 European nations 1995-2011. Health Policy, 115 (1), 1-8. doi: http://doi.org/10.1016/ j.healthpol.2013.11.008

4. Braithwaite, J., Hibbert, P., Blakely, B., Plumb, J., Hannaford, N., Long, J. C., Marks, D. (2017). Health system frameworks and performance indicators in eight countries: A comparative international analysis. SAGE Open Medicine, 5. doi: http://doi.org/10.1177/ 2050312116686516

5. Kutzin, J. (2012). Anything goes on the path to universal coverage? No. Bulletin of the World Health Organization, 90 (11), 867-868. doi: http://doi.org/10.2471/blt.12.113654

6. Rechel, B. (2019). Funding for public health in Europe in decline? Health Policy, 123 (1), 21-26. doi: http://doi.org/10.1016/j.healthpol.2018.11.014

7. Loughnane, C., Murphy, A., Mulcahy, M., McInerney, C., Walshe, V. (2018). Have bailouts shifted the burden of paying for healthcare from the state onto individuals? Irish Journal of Medical Science, 188 (1), 5-12. doi: http://doi.org/10.1007/ s11845-018-1798-x

8. Brousselle, A., Benmarhnia, T., Benhadj, L. (2016). What are the benefits and risks of using return on investment to defend public health programs? Preventive Medicine Reports, 3, 135-138. doi: http://doi.org/10.1016/j.pmedr.2015.11.015

9. Nichols, L. M., Taylor, L. A. (2018). Social Determinants As Public Goods: A New Approach To Financing Key Investments In Healthy Communities. Health Affairs, 37 (8), 1223-1230. doi: http://doi.org/10.1377/hlthaff.2018.0039

10. Stuckler, D., Reeves, A., Mckee, M. (2017). Social and economic multipliers: What they are and why they are important for health policy in Europe. Scandinavian Journal of Public Health, 45 (18), 17-21. doi: http://doi.org/10.1177/1403494817707124

11. Lee, J. T., Majeed, A., Millett, C. (2012). User fees in universal health systems. The Lancet, 380 (9854), 1643-1644. doi: http://doi.org/10.1016/s0140-6736(12)61941-2

12. Towards actionable international comparisons of health system performance: expert revision of the OECD framework and quality indicators. (2015). International Journal for Quality in Health Care, 27 (2), 137-146. doi: http://doi.org/10.1093/intqhc/mzv004

13. Perić, N., Hofmarcher-Holzhacker, M. M., Simon, J. (2017). Health system performance assessment landscape at the EU level: a structured synthesis of actors and actions. Archives of Public Health, 75 (1). doi: http://doi.org/10.1186/s13690-016-0173-5

14. Tanza Loudenback The average cost of healthcare in 21 different countries (2019). Business insider Australia. Available at: https://www.businessinsider.com.au/cost-of-healthcare-countries-ranked-2019-3

15. Burbela, A. L. (2017). Derzhavni vytraty na okhoronu zdorovia v Ukraini. Naukovyi visnyk Uzhhorodskoho natsionalnoho universytetu vypusk, 14 (1), 37-40.

16. Carrera, P. M. (2018). Social Determinants Of Health As Public Goods. Health Affairs, 37 (10), 1710. doi: http://doi.org/10.1377/hlthaff.2018.1115

17. Sachs, J. D. (2012). Achieving universal health coverage in low-income settings. The Lancet, 380 (9845), 944-947. doi: http://doi.org/10.1016/s0140-6736(12)61149-0

18. Jowett, M., Brunal, M. P., Flores, G., Cylus, J. (2016). Spending targets for health: no magic number. Geneva: World Health Organization; 2016 (WHO/HIS/HGF/HFWorkingPaper/16.1; Health Financing Working Paper No. 1). Available at: http://apps.who.int/iris/bitstream/10665/250048/1/WHO-HIS-HGFHFWork $\urcorner$ ingPaper-16.1-eng.pdf

19. White, J. (2013). Budget-makers and health care systems. Health Policy, 112 (3), 163-171. doi: http://doi.org/10.1016/ j.healthpol.2013.07.024

20. WHO. European Health Information Gateway. Available at: https://gateway.euro.who.int/en/

21. Wilson, K. (2016). Innovation and sustainability of European healthcare systems. Bruegel Blog. Available at: https://www.bruegel.org/2016/01/innovation-and-sustainability-of-european-healthcare-systems/?utm_content=buffer1ba87\&utm_medium= social\&utm_source=twitter.com\&utm_campaign=buffer+(bruegel) 
22. Tsurikova, O. V. (2019). A comparative analysis of the dynamics of cash payments of families for medical and pharmaceutical services among the total health spending in Ukraine, Azerbaijan, Armenia, Georgia. Social Pharmacy in Health Care, 5 (4), 31-39. doi: http://doi.org/10.24959/sphhcj.19.171

23. Tereshchenko, L., Zhirova, I. (2019). Analysis of the dynamics of expenditures on pharmaceutical support of population in Ukraine, Belarus republic and in European Union. ScienceRise: Pharmaceutical Science, 4 (20), 10-14. doi: http://doi.org/10.15587/ 2519-4852.2019.177193

24. National strategy for reforming the health care system in Ukraine for the period 2015-2020. Ministry of Health of Ukraine. International Renaissance Foundation. 2015. Available at: https://moz.gov.ua/uploads/0/691-strategiya.pdf

25. McDaid, D., Quaglio, G., Correia de Campos, A., Dario, C., Van Woensel, L., Karapiperis, T., Reeves, A. (2013). Health protection in times of economic crisis: Challenges and opportunities for Europe. Journal of Public Health Policy, 34 (4), $489-501$. doi: http://doi.org/10.1057/jphp.2013.35

Received date 08.06.2020

Accepted date 24.06.2020

Published date 30.06.2020

Oleh Samborskyi, PhD, Associate Professor, Department of Organization and Economics of Pharmacy and Drug Technology, State higher educational institution «Ivano-Frankivsk National Medical University», Halytska str., 2, Ivano-Frankivsk, Ukraine, 76018

E-mail: aptekar05@ukr.net

Mykola Slobodyanyuk, Doctor of Pharmaceutical Sciences, Professor, Department of Pharmaceutical Marketing and Management, National University of Pharmacy, Pushkinska str., 53, Kharkiv, Ukraine, 61002 E-mail: veritas_kh@ukr.net

Hanna Panfilova, Doctor of Pharmaceutical Sciences, Professor, Department of Organization and Economics of Pharmacy, National University of Pharmacy, Pushkinska str., 53, Kharkiv, Ukraine, 61002

E-mail: panf-al@ukr.net 